\title{
21st Century Skills in Business and Maria Montessori
}

\author{
Betul Kuru \\ Istanbul University, Faculty of Business, \\ Organizational Behavior Department, Istanbul, Turkey \\ E-mail: betul.kuru@okan.edu.tr
}

\begin{abstract}
In recent years, educators and workforce experts have been seeing a consensus that the new generation needs the improved skills of the 21st century. Without these skills, it is thought that the new generation cannot successfully participate in the global economy and cannot be prepared enough for the university and business life. In this study, the effectiveness of Montessori Education Approach was evaluated in the acquisition of 21 st century skills. An early childhood model proposal was developed by identifying the aspects of this education method, which began a century ago and continued to be developed until 1952, and which is still valid today, are similar to 21 st century skills. The 21 st century skills that the P21 platform categorized and divided into themes were based on. Matching expressions of 21 st century skills and principles in Montessori education were examined. The findings obtained revealed a total of 963 matching expressions of the 21st century skills and the Montesoori education approach. The fact that the Montessori method, which cannot be widely used in our country due to its financial dimension, can be placed in the National Education preschool education program, may be the correct model, and other modern education methods (Experiential education), High-Scope Regio-Emillia Sweden Program (Whariki) are evaluated and our education system It has been suggested that the most appropriate pre-school education model should be prepared urgently.
\end{abstract}

Keywords: 21st century skills, Maria Montessori, business and preschool education, education policies

\section{Special Issue of Educational Sciences}

DOI: $10.7176 / J S T R / 6-06-15$

\section{İş Dünyasında 21. Yüzyıl Becerileri ve Maria Montessori}

\begin{abstract}
ÖZET
Son yıllarda eğitimciler ve iş gücü uzmanları yeni neslin 21.yüzyılın geliştirilmiş becerilerine ihtiyaç duydukları konusunda görüş birliği içinde olduklarını görmekteyiz. Bu beceriler olmadan, yeni neslin küresel ekonomiye başarıyla katılamayacağ 1 , üniversite ve iş hayatı için yeterince hazırlıklı olamayacağ düşünülmektedir. Bu çalışmada 21. yüzyıl becerilerinin kazanılmasında Montessori Eğitim Yaklaşımının etkinliği değerlendirilmiştir. Yüzyıl önce başlayıp 1952 lere kadar geliştirilmeye devam edilen ve günümüzde halen geçerliliğini koruyan bu eğitim yönteminin 21 yüzyıl becerileri ile benzeşen yönleri tespit edilerek bir erken çocukluk modeli önerisi geliştirilmiştir. Çalışmada P21 platformunun kategorilendirip temalara ayırdığı 21.yüzyıl becerileri esas alınmıştır. 21. yüzyıl becerileri ve Montessori eğitimindeki esasların eşleşen ifadeleri incelenmiştir. Elde edilen bulgular 21. yüzyıl becerileri ile Montessori Eğitim Yaklaşımının toplam 963 sayıda eşleşen ifadesini ortaya koymuştur. Ülkemizde mali boyutu nedeni ile kullanılması yaygınlaşamayan Montessori Yönteminin Milli Eğitim Okul Öncesi Eğitim Programının içine yerleştirilmesinin doğru bir model olabileceği ve diğer modern eğitim yöntemlerinin de (Deneyimsel eğitim (experimential education),High-Scope Regio-Emillia Ísveç Programı (Whariki) değerlendirilip eğitim sistemimiz için en uygun okul öncesi eğitim modelinin acilen hazırlanmasının gerekliliği önerisinde bulunulmuştur.
\end{abstract}

Anahtar Kelimeler: 21 yüzyıl becerileri, Maria Montessori, iş dünyası ve okul öncesi eğitim, eğitim politikaları 


\section{I-GíRIŞ}

21. yüzyılın ilk çeyreğini yaşadığımız şu günlerde işletmeler kendileri için en önemli sermaye unsurunun insan olduğu gerçeğini kabul etmişlerdir. İşletmelerin bilgili, entelektüel özellikleri taşıyan, yaratıcı, sorgulayıcı, yenilikçi ve araştırmacı insanlara olan gereksinimi hızla artmaktadır. Günümüz insanından beklenen bilgiyi ezberine alması değil her alanda ona hızlı ulaşması, paylaşması ve onu etkin kullanmasıdır. Bunun için bireye kazandırılması ve geliştirilmesi gereken belli beceriler vardır. Öğrencileri hem ulusal hem uluslararası düzeyde kişisel, akademik ve iş hayatlarında ihtiyaç duyacakları yeterlilik ve becerilerle donatacak eğitim programlarının geliştirilmesi aciliyet gerektiren konular arasında olmalıdır. Yaratıcılık, eleştirel düşünme, problem çözme ve işbirlikli çalışma gibi becerilerin, sanayi dönemi formatına sahip klasik eğitim anlayışı ile çocuklara kazandırılması pek de mümkün görünmemektedir (Ercenk, H., 2019). Özellikle çocukların, zihinsel, duygusal, sosyal, bedensel gelişiminin \% 70'ini tamamladığı okul öncesi dönem olarak adlandırılan 0-6 yaş dönemi, çocuğun öğrenmesinin en yoğun olduğu, temel alışkanlıklarının, zihinsel yeteneklerinin en hızlı geliştiği ve biçimlendiği dönemdir. Bu süre içerisinde kazanılan davranış biçimleri, tüm yaşam boyunca devam etmektedir. Beyin yapısı ve fonksiyonlarının gelişiminin üçte ikilik bölümü 0-4 yaş arasında tamamlanmaktadır.

Erken çocukluk dönemindeki deneyimler beynin çalışma biçimi için belirleyicidir. Okul öncesi dönemin iş hayatı için ne kadar önemli olduğunu Chicago Üniversitesinden Nobel ödüllü Ekonomist Prof. Dr. James J. Heckman'ın şu sözlerinden anlayabiliriz “Çocuklara yatırım yapmak için onların birer yetişkin olmasını beklemek lüksümüzün olmadı̆̆ gibi, onlar okula başlayana kadar bekleme lüksümüzde yok. Çünkü o zaman müdahale etmek için çok geç olabilir" (dersimizturkce.com/erken cocukluk programı tanıtımı: 1) $\mathrm{Bu}$ çalışmada 21.yy becerileri ile Montessori Yaklaşımının ilişsisini ortaya koyarak, bireyleri beceri ve yetkinlik temelli bir hayata hazırlayacak okul öncesi eğitim politikasına öneriler geliştirmek amaçlanmıştır. $\mathrm{Bu}$ eğitim politikası önerileri 21.yy becerilerini kazanmış bireylerin olduğu Türkiye nin küreselleşen Dünyada daha güçlü ve etkin olmasına hizmet edebilecektir. Erken çocukluk eğitiminin sınırlı ve yetersiz kalması, insan sermayesi veya beşeri sermayenin gelişimini sınırlandırmaktadır. Bu da insani gelişme ve ekonomik büyümeyi yavaşlatmaktadır. Daha sonraki süreçlerde yapılan yatırımlar yoğun olsa bile, eğer erken çocukluk döneminde yetersiz kalınmışsa yatırımların getirisi ve bunların ekonomik büyümeye etkisi daha düşük olmaktadır. Bu nedenle insani gelişim ve ekonomik büyüme icin erken çocukluk dönemine yönelik daha geniş araştırmaların ve doğru eğitim politikalarının oluşturulması gereklidir.

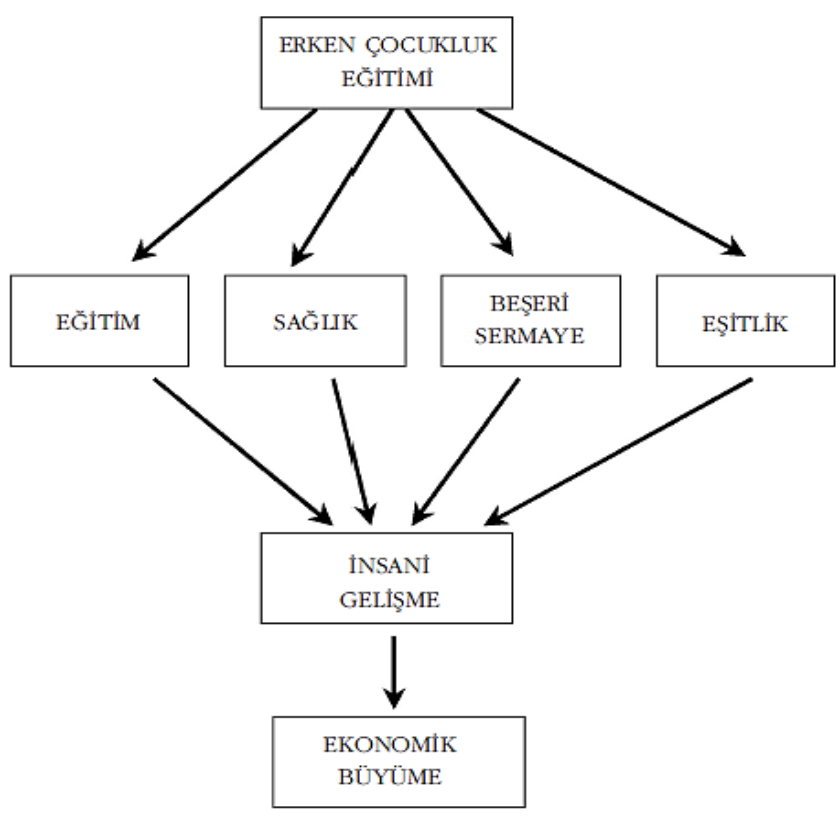

Şekil 1. Erken Çocukluk Eğitimi ve Ekonomik Büyüme İlişkisi (Tüsiad, 2005) 


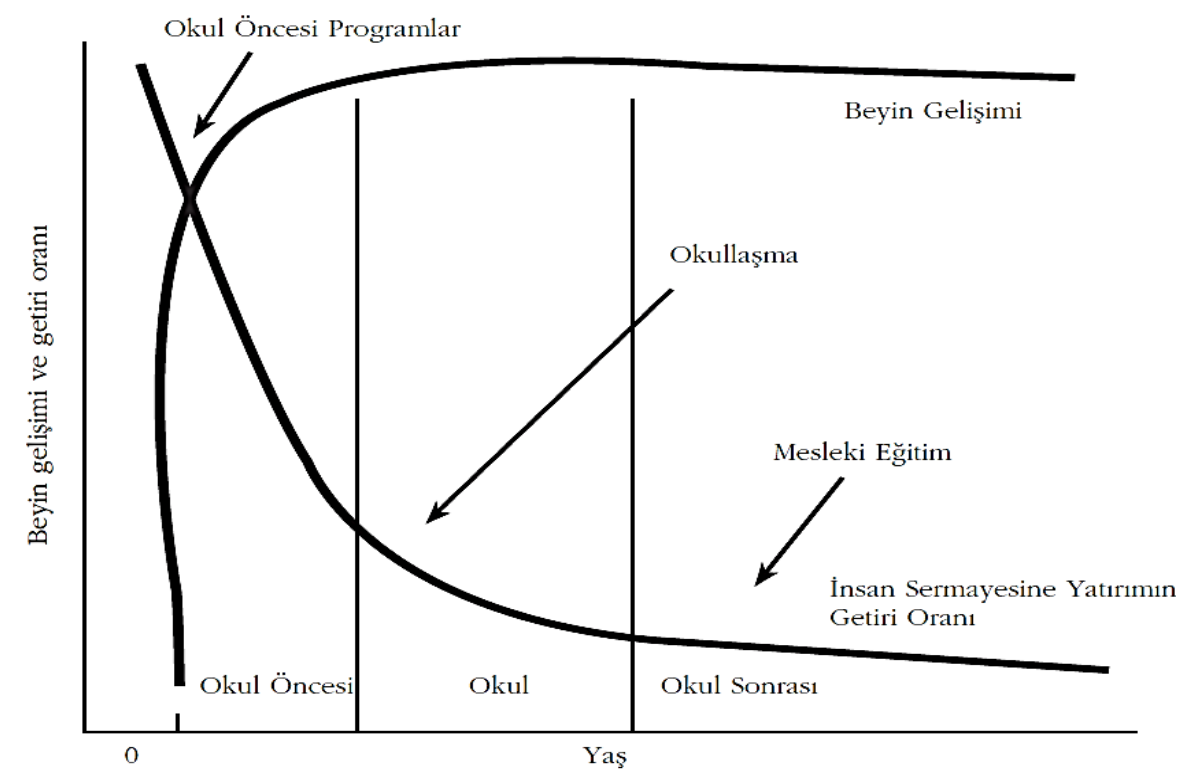

Şekil 2. Beyin Gelişimi ve Getiri Oranı (Tüsiad, 2005)

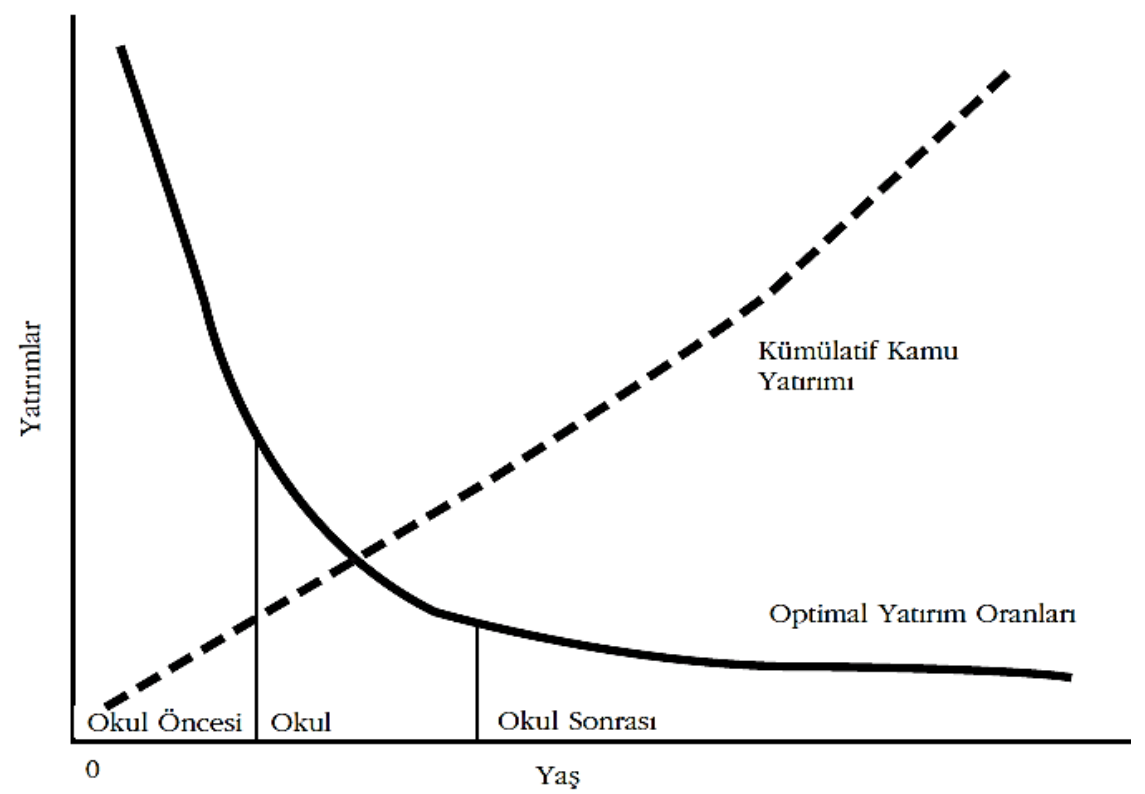

Şekil 3. Optimal ve Gerçek Yatırım ( Tüsiad, 2005)

Yukarıda ki şekil 1.2.3 de de görüldüğü gibi erken çocukluk dönemindeki yatırımların getirisi en yüksek olmaktadır. Bu, insani gelişme ve ekonomik büyüme için insan sermayesine yatırımın erken çocukluk dönemlerinde yoğunlaştırılması gereğini ortaya koymaktadır.

\section{KAVRAMSAL ÇERÇEVE}

\section{A.21. Yüzyll Becerileri}

21. yüzyıl becerilerini genel anlamıyla bilgi çağında yaşayan bireylerin etkin ve nitelikli olabilmeleri için taşımaları ve sürekli geliştirmeleri gereken beceri setleri olarak ifade edebiliriz. 21. yüzyıl becerilerine yönelik çeşitli kurum ve kuruluşlar farklı tanım ve öncelikler belirlemişlerdir. Bunlardan en bilineni 2002'de Amerika Birleşik Devletleri'nde (ABD) iş dünyası, eğitim liderleri ve politika yapıcıları 21. yüzyılın bireylerini hazırlamak amacıyla bir araya getiren P21 (Partnership for 21st Century Learning-21. Yüzyıl 
Becerileri İçin Ortaklık) oluşumudur. 21. yüzyıl becerileri üç ana kategoride toplanmaktadır. Bunlar öğrenme, okuryazarlık ve gündelik hayatla ilgili becerilerdir. Bunlar her alanda etkilediği bireyin gündelik ve meslek hayatında sahip olması ve göstermesi gereken becerilerin değişimini göstermektedir. Bireylerin yanı sıra günümüzde öğrenci, öğretmen, okul yöneticisi ve velilerden beklenen becerilerin de analiz edilmesi oldukça önem arz etmektedir. Becerilerle ilgili dünya çapında en çok kabul gören ve genel tasnif P21'in hazırladığıdır. Bu çalışmada tablo 1 de tanımları ile birlikte yer alan P21 becerileri esas alınmıştır.

Tablo 1. Tanımları ile 21.Yüzyıl Becerileri

\begin{tabular}{|c|c|}
\hline BECERİ & TANIM \\
\hline Okuryazarl1k & Yazılı dili okuma, anlama ve kullanma \\
\hline Aritmetik & $\begin{array}{l}\text { Sayılar ve diğer sembollerden yararlanarak sayısal ilişkileri anlama ve } \\
\text { ifade etme }\end{array}$ \\
\hline Bilimsel Okuryazarlık & $\begin{array}{l}\text { Kişinin bilimsel bilgi ve yöntemleri kullanarak çevresini test etmesi ve } \\
\text { hipotezlerini sınaması }\end{array}$ \\
\hline $\begin{array}{l}\text { Bilgi ve İletişim Teknolojileri } \\
\text { Okuryazarlı̆̆1 }\end{array}$ & $\begin{array}{l}\text { Bilgi edinme ve paylaşma, soruları yanıtlama, diğer insanlarla } \\
\text { etkileşimde bulunma ve bilgisayar programlamayı da içeren teknoloji } \\
\text { tabanlı içerik kullanma ve oluşturma }\end{array}$ \\
\hline Finansal Okuryazarlık & $\begin{array}{l}\text { Finansin kavramsal ve sayısal yönlerini pratik olarak anlama ve } \\
\text { kullanma }\end{array}$ \\
\hline $\begin{array}{l}\text { Kültürel ve Yurttaşlık } \\
\text { Okuryazarlığ }\end{array}$ & Beşeri bilimleri anlama, analiz etme, takdir etme ve bilgiyi uygulama \\
\hline YETKİNLİKLER & TANIM \\
\hline $\begin{array}{l}\text { Eleştirel Düşünme/Problem } \\
\text { Çözme }\end{array}$ & $\begin{array}{l}\text { Yanit ve çözümleri formüle etmek için durum, fikir ve bilgileri } \\
\text { belirleme, analiz etme ve değerlendirme }\end{array}$ \\
\hline Yaratıcilık & $\begin{array}{l}\text { Problemleri çözme, sorulara cevap verme, uygulama yoluyla ifade etme, } \\
\text { sentezleme ya da yeniden anlamlandırma yoluyla anlam ifade etme gibi } \\
\text { yeni ve yenilikçi yöntemler tasarlama }\end{array}$ \\
\hline İletişim & $\begin{array}{l}\text { Sözel, sözel olmayan, görsel ve yazılı yollarla bilgiyi dinleme, anlama, } \\
\text { iletme ve bağlamsallaştırma }\end{array}$ \\
\hline İş Birliği & $\begin{array}{l}\text { Çatışmayı önleme ve yönetme yeteneği de dahil olmak üzere ortak bir } \\
\text { hedefe doğru takım çalışması }\end{array}$ \\
\hline KARATER NITTELİ̆́̇̇ & TANIM \\
\hline Merak & Soru sorma, açık fikirlilik ve merakını gösterebilme \\
\hline Girişimcilik & $\begin{array}{l}\text { Girişimcilik Proaktif olarak yeni bir görev ya da hedef üstlenmek için } \\
\text { gerekli yetenek ve isteğe sahip olma }\end{array}$ \\
\hline Süreklilik ve Dayanıklılık & $\begin{array}{l}\text { İlgi ve çabayı sürdürebilme, bir görevi veya hedefi gerçekleştirmeye } \\
\text { devam edebilme }\end{array}$ \\
\hline Uyumluluk & $\begin{array}{l}\text { Yeni bilgiler ışığında planları, yöntemleri, görüşleri veya hedefleri } \\
\text { değiştirebilme }\end{array}$ \\
\hline Liderlik & $\begin{array}{l}\text { Ortak bir hedefe ulaşmak için başkalarını etkili bir şekilde } \\
\text { yönlendirebilme, doğrudan etkileyebilme ve ilham verebilme }\end{array}$ \\
\hline Sosyal ve Kültürel Farkındalık & $\begin{array}{l}\text { Sosyal, kültürel ve etik açıdan uygun bir şekilde diğer insanlarla } \\
\text { etkileşim kurabilme }\end{array}$ \\
\hline
\end{tabular}

(World Economic Forum Raporu, 2015)

\section{B-Maria Montessori Eğitim Yöntemi}

Montessori eğitim programı iki buçuk-altı yaş çocuklarını kapsayan özgüven, insiyatif, ne istediğini bilme ve uygulama, bağımsızlık, konsantrasyon, düzenlilik, yardımlaşma ve başkalarına karşı saygıyı yerleştirme ve geliştirme üzerine odaklanmıştır. İtalyan Profesör Maria Montessori tarafından ortaya atılan çocuk merkezli bir eğitim sistemi olan bu eğitim modeli; Almanya, İtalya, Amerika başta olmak üzere dünyanın birçok ülkesinde en yaygın eğitim modeli olarak kabul görmektedir. Montessori 'insan doğuştan iyiye 
yöneliktir ve esas amacı kendini ispatlamaktır' prensibini benimser. Prescott Lecky, Carl Rogers ve Abraham Maslow gibi kişilik teorisi geliştiren yazarlarla Montessori'nin okul öncesi çocukları için geliştirdiği eğitim metodu arasında büyük bir paralellik vardır. Montessori de belirtilen kişilik kuramcıları gibi kişilik gelişimi üzerinde önemle durur (Montessori 1964). Montessori yaklaşımında önemli olan bazı ana hatlar vardır ve eğitimin temelini oluşturmaktadır.

\section{B.1 Sinıf Düzeni Gerçek Hayata Uygundur}

Montessori sınıflarında her nesnenin bir örneği bulunur ve çocuklardan biri o an başka bir çocuk tarafından kullanılan bir parçayı istediğinde sırasını bekler. $\mathrm{Bu}$ da önemli toplumsal erdemler doğurur. Çocuğun yaşadığı deneyimlerden başka bir erdem daha ortaya çıkar: Sabırlı olmak. Üç yaşındaki bir çocuğa böyle bir ahlâkı öğretmek mümkün değildir. Bunu ancak deneyim öğretebilir ve insanlar diğer koşullar altında çocukları istedikleri şeyleri almak için kavga ederken görmeye alıştıklarından dolayı, Montessori okullarında çocukların onlara emreden kimse olmamasına rağmen sıra beklemesi karşısında şaşırırlar. Oysa bunu yapan özenle hazırlanmış çevre ve çocukların bu çevrede bulduğu özgürlüktür (Montanaro,1991:99101).

\section{B.2 Sınıflar Geleneksel Sınıflara Göre Çok Daha Geniştir}

Montessori sınıfları geleneksel okulların aksine bir hayli büyük olduğundan, karakter farklılıkları daha açık bir şekilde kendini gösterir ve bu da daha fazla deneyim yaşanmasına olanak verir. Küçük sınıflarda bu o kadar da kolay değildir (Williams, 1996).

\section{B.3 Karma Eğitim Sistemi Uygulanır ve Her Sınıfta İki Veya Üç Öğretmen Bulunur}

Sınıflarda karma yaş sistemi uygulanır ve 3-6 yaş arası çocuklar bir aradadır. Böylelikle küçükler büyüklerin yaptıklarını görür ve açıklamalarını isterler. İstedikleri açıklamayı da hemen alırlar ve bu da gerçekten değerli bir ders olur. 5 yaşındaki bir çocuğun zihni 3 yaşındaki bir çocuğun zihnine çok daha yakındır. Bu yüzden bizim anlatmakta zorlanacağımız bir şeyi küçükler birbirlerine kolaylıkla öğretebilirler. Büyüklerde de sorumluluk ve küçüklerini koruyup sahiplenme duyguları gelişir. Her iki tarafta da sevgi ve hayranlık, gerçek bir kardeşlik söz konusudur. (Montanaro,1991).

\section{B.4 Ödül ve Ceza Sistemi Yoktur}

Montessori yönteminde çocuğun başarıları ya da iyi davranışları ödülle değerlendirilmez. İstenen o olumlu sonucun kendisidir. Matematikte kırmızı - mavi çubukları sıralamak ve sayı kartlarını doğru yerleştirmek mücadelenin başarıyla sonuçlandığının göstergesidir, çocuk bu işi sonucunda yakasına takılacak bir süs için yapmamıştır, çocuğun amacı öğrenmekten alacağı keyiftir. Ödülün olmaması gibi ceza da yoktur, çocuklar olumsuz davranışın doğal ya da mantıksal sonucunu bizzat yaşar. Ceza çocuğun davranışının bir yetişkin tarafindan değerlendirilmesidir, bu durum her zaman fazla ya da eksik değerlendirme nedeniyle cezanın gereğinden fazla ya da az verilmesiyle sonuçlanır. Bu, çocuğun davranışının sonucunu yanlış anlamasına yol açar. Çocuk tecrübe kazanamamış olur (Williams, 1996).

\section{B.5 Çocuk Kendi Öğrenme Süresini Kendi Belirler}

Geleneksel eğitim modelinde öğretmen çocuğun öğrenme hızına bakmadan kendi günlük planına göre ilerlemeye çalışır. Bu da kimi çocukların sıkılmasına yol açarken kimi çocukların da gerekli kazanımı elde edemeden diğer çalışmalara geçilmesine sebep olur. Çocuklar arasındaki rekabet ve kıskançlık hat safhaya çıkar. Montessori' de ise her çocuk için bireysel bir plan hazırlanır. Çocuk öğrenme süresini kendi belirler. Çocuklara istedikleri kadar tekrar etme imkânı sunulur. Erken öğrenen yeni bir çalışmaya geçebilecektir. Çünkü öğrenmede herkesin farklı bir ritmi vardır(Castrelli, 1943).

\section{B.6 Çocuklar Aynı Sınıf ve Zamanda İlgi Ve Yeteneklerine Göre Farklı Alanlarda Çalışabilir}

Geleneksel eğitim modelinde bütün çocuklar öğretmen tarafından aynı etkinliği yapmaları için yönlendirilir hatta zorlanır. Bu durum kimi çocukların etkinlikten keyif almamasına ve çevresini rahatsız etmesine yol açar. Montessori eğitim sisteminde ise çocuklar İstedikleri materyalle, istedikleri zaman, istedikleri yerde çalışabilirler. İlgileri doğrultusunda çalışabildikleri için okuldan keyif alırlar. (Montanaro,1991).

\section{B.7 Çocuk Kendi "Hata Kontrolu"Nu Kendi Yapar}

Materyallerdeki hata kontrolü çocuğun kendi hatasını bulmasıyla gerçekleşir. Başka birinden uyarıya, onaya ve düzeltmeye gerek kalmaz. Kendi kendisini düzeltmesine olanak sağlanır. Böylece yetişkinden bağımsızlaşmak doğal olarak gerçekleşir (Kramer, 1976 ). 


\section{ARASTTIRMANIN YÖNTEMI}

\section{A. Araştırma Yöntemi ve verilerin analizi}

Nitel araştırma türünde olan bu araştırmada, veriler içerik analizi yöntemi ile incelenmiştir. Maria Montessorinin biyografisi, otobiyografisi, eğitim modelini tanıttığı kendi kitabı ve bu eğitim modeli hakkında yazılan diğer kitaplar, makaleler kaynaklar taranmış, Maria Montessori ve eğitim sistemi hakkındaki filimler izlenmiş, Montessori eğitimi veren okul öncesi kurumlar ziyaret edilmiştir ve Montessori eğitim yöntemi araştırmacı tarafından kategorilere ayrılmıştır. 21 yüzyıl becerileri ile ilgili çeşitli kurumların yayınladığı raporlar ve kategorilendirmeler incelenmiş eğitim programları ile en uyumlu olan P21 platformunun yaptığ sınıflama esas alınmıştı ve yeniden kategorileştirilmeden olduğu şekli ile kullanılmıştır. 21. Yüzyıl becerileri kategorileri ile örtüşen Montessori eğitim yönteminin ilkeleri tespit edilmiş ve örtüşen ifadeler ilgili 21 yy kategorilerinin altında birleştirilmiştir. Örtüşen ifadelerin ilgili olduğu 21. yy kategorilerinin tespiti araştırmacı tarafından yapılarak, okul öncesi alanında çalışan 2 ayrı akademisyene de sunularak tekrar düzenleme yapılmıştır.

\section{B. Araştırma Sorusu ve Modeli}

Çalışmada 21. Yüzyıl becerilerinin öğrencilere kazandırılması için Maria Montessori Eğitim Yönteminin katkısı ile nasıl bir okul öncesi eğitim modeli olmalıdır? Sorusuna cevap aranmıştır. Araştırmanın modeli şekil 4 de yer almaktadır.

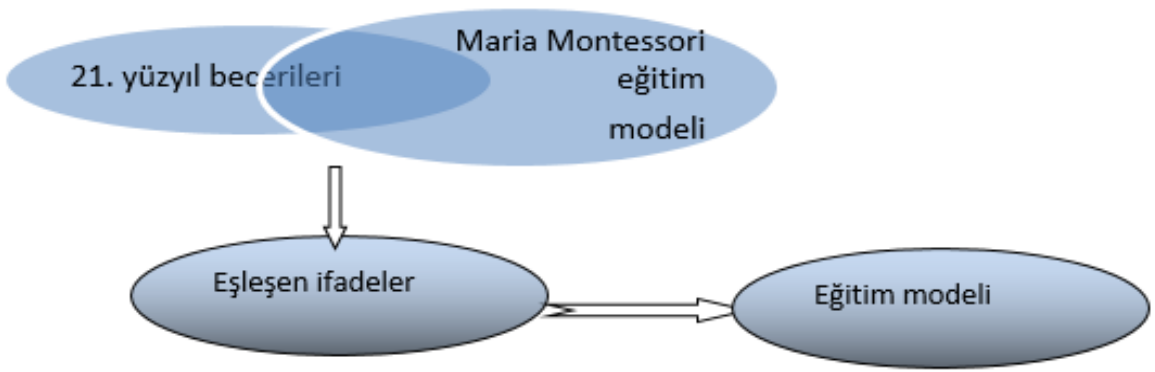

Şekil 4 (Araştırma Modeli)

\section{C.Araştırmanın Bulguları}

Maria Montessori eğitim modelinin günümüz 21. yüzyıl becerileri ile örtüşen söylemleri bulmak için öncelikle Montessori eğitim yönteminin ana hatları kategorileştirilmiştir. Bu kategorilere denk gelen 21 . Yy becerileri ile eşleştirilmiştir. Tablo 3 de bu eşleştirmelerin frekans tablosu vardır. Tablo Montessori ifadelerinin nasıl kategorilere ayrıldığı ile ilgili örnekler yer almaktadır. (Tüm ifadeler yazardan mail olarak alınabilir.)

Tablo 2 Örnek kategorilendirme

\begin{tabular}{|l|l|l|}
\hline Maria Montessori Söylemleri & $\begin{array}{l}\text { 21. yy becerileri } \\
\text { kategoriler }\end{array}$ & $\begin{array}{l}\text { Maria Montessori } \\
\text { kategorileri }\end{array}$ \\
\hline $\begin{array}{l}\text { Çocuklar bir materyalin gösteriminden sonra } \\
\text { yapmaları konusunda teşvik edilmeli ama asla } \\
\text { zorlanmamalıdır }\end{array}$ & Merak & Duyuların eğitimi \\
\hline $\begin{array}{l}\text { Çocuğa kazandırılan yeni bilgiler çocuk için adeta } \\
\text { "dünyanın anahtarı” dır,çocuk burada edindiği yeni } \\
\text { bilgiler ile çevresinde gördükleri arasında bağ } \\
\text { kurarak bilinçlenir }\end{array}$ & Bilimsel Okuryazarlık & Duyuların eğitimi \\
\hline
\end{tabular}


International Journal of Scientific and Technological Research

ISSN 2422-8702 (Online), DOI: 10.7176/JSTR/6-06-15

Special Issue of Educational Sciences, Vol.6, No.6, 2020

Tablo 3 Örtüşen İfadeler Frekans Tablosu

\begin{tabular}{|c|c|c|}
\hline 21. Yüzyıl becerileri & Montessoori Eğitim yaklaşımı & $\begin{array}{l}\text { Örtüssen söylemler } \\
\text { frekanı }\end{array}$ \\
\hline Okuryazarlık & Dil geliştirici etkinlikler/Dil gelişimi/ Duyuların Eğitimi & 68 \\
\hline Aritmetik & Matematik Etkinlikleri & 75 \\
\hline Bilimsel Okuryazarlık & $\begin{array}{l}\text { Absorbe eden Zihin (Emici Bellek) } \\
\text { Duyuların eğitimi/ Hareket ve duyu etkinliği/ Çocuğun } \\
\text { bireyselliği/ Günlük yaşam becerileri/ Bireysel eğitim/ } \\
\text { Uygun çevre }\end{array}$ & 33 \\
\hline $\begin{array}{l}\text { Bilgi ve İletişim } \\
\text { Teknolojileri Okuryazarlığ }\end{array}$ & Uygun çevre/ Matematik Etkinlikleri /Duyuların eğitimi & 24 \\
\hline Finansal Okuryazarlık & Matematik Etkinlikleri & 16 \\
\hline $\begin{array}{l}\text { Kültürel ve Yurttaşlık } \\
\text { Okuryazarlığ } 1\end{array}$ & $\begin{array}{l}\text { Bilinç/ Uygun çevre/Kozmik eğitim/ Kendini } \\
\text { biçimlendirme/ Dünyaya dönük olma/ Bireysel eğitim }\end{array}$ & 53 \\
\hline $\begin{array}{l}\text { Eleştirel Düşünme/Problem } \\
\text { Çözme }\end{array}$ & Oyun /Bilinç/ Uygun çevre/Duyuların eğitimi & 56 \\
\hline Yaratıcıllk & Kendini biçimlendirme/ Uygun çevre & 59 \\
\hline İletişim & Normalleşme & 55 \\
\hline İş Birliği & $\begin{array}{l}\text { Dünyaya dönük olma/ Uygun çevre /Oyun / Matematik } \\
\text { Etkinlikleri/ }\end{array}$ & 68 \\
\hline Merak & Duyuların eğitimi/ Bilinç/ Çocuk merkezli eğitim & 74 \\
\hline Girişimcilik & $\begin{array}{l}\text { Duyuların eğitimi/ Günlük yaşam becerileri/ Özgürlük/ } \\
\text { Düzenlenmiş } \\
\text { Çevre(uygun çevre) }\end{array}$ & 82 \\
\hline Süreklilik ve Dayanıklılık & $\begin{array}{l}\text { Hareket ve duyu etkinliği/ Normalleşme/ Düzenlenmiş } \\
\text { Çevre (uygun çevre) / Duyuların Eğitimi }\end{array}$ & 79 \\
\hline Uyumluluk & $\begin{array}{l}\text { Düzene karş1 Duyarlılık/ Uyum sağlama/ Kendini } \\
\text { biçimlendirme/ Uygun çevre/ Duyuların eğitimi }\end{array}$ & 83 \\
\hline Liderlik & $\begin{array}{l}\text { Karma yaş sistemi/ Düzenlenmiş } \\
\text { Çevre }\end{array}$ & 75 \\
\hline $\begin{array}{l}\text { Sosyal ve Kültürel } \\
\text { Farkındalık }\end{array}$ & $\begin{array}{l}\text { Özgürlük ve Disiplin/ Düzene karşı duyarlılık/ Duyarlılık } \\
\text { dönemleri }\end{array}$ & 63 \\
\hline TOPLAM & & 963 \\
\hline
\end{tabular}

\section{SONUÇ VE TARTIŞMA}

$\mathrm{Bu}$ yüzyılın başından itibaren küresel ve yerel anlamda pek çok ülkede eğitim alanında gündem yaratan pek çok tartışma ve politikalar yapılmıştır. Bunun nedeni özellikle 20. yüzyılın üçüncü ve dördüncü çeyreğinde insanlığın hayatında inanılmaz değişiklik yapan bilgisayar ve internetin var olan eğitim paradigmalarını etkilemesidir. Bu etkilenmeden dolayı ülkelerin öncü eğitimcileri 21. yüzyıl becerileri odağında öğrencileri beceri ve yetkinlik temelli bir hayata hazırlama politikası içeren eğitim modelleri geliştirmişlerdir. Ülkemiz 21.yy en başından itibaren bu konuda bazı adımlar atmıştır. Sistemi bütünü ile kapsayamasa da ve yalnızca

$\mathbf{1 9 4}$ | P a g e

WWW.iiste.org 
bir ya da birkaç boyuta odaklanılsa da bazı olumlu değişimler olmuş ancak beklenen değişim gerçekleşememiştir. Milli Eğitim Bakanlığının Ocak-2019 da yayınladığı 2023 Eğitim Vizyon Belgesi'nde 21 yy becerilerini doğrudan bir bölüm ve hedef olarak yer vermesi Türkiye'nin eğitim politikalarında 21 yy becerilerine daha fazla ağırlık verileceğini bize göstermektedir.

Montessori eğitimi, çocuğa var olan hazır bilgiyi dayatmaz. Çocuğun doğasında var olduğu bilinen öğrenme isteğini gerçekleştirecek programlara yönelik bir eğitim yöntemidir. Çalışmanın sonucunda ulaşılan (araştırmacının ulaştığı kaynakların taranması sonucu 963 eşleşme tespit edilmiştir, çok geniş olan Montessori eğitim kaynaklarına tamamen ulaşılabilse bu sayının 3-4 kat daha artacağı düşünülmektedir ) eşleşen ifadelerin çokluğu, 21. yy becerilerinin kazanılmasında okul öncesi eğitim politikaları oluşturulurken mutlaka Montessori eğitim modelinden yararlanılmasının gerekliliğini ortaya koymaktadır. Montessori eğitimi almış ve yenidünya paradigmalarına yön vermiş kişilere bakınca da çalışmanın sonuçlarının ne derece doğru olduğunu ve okul öncesinde Montessori Eğitiminin neden eğitim politikalarımızda yer alması gerektiğini bir kez daha anlıyoruz. Okul öncesi dönemde Montessori eğitimi almış bazı ünlüler; Gabriel Garcia Marquez (Romancı, hikâyeci, oyun yazarı, Nobel ödüllü Kolombiyalı yazar) Anne Frank (İlk Yahudi kadın yazarı, Yahudi soykırımı simgesi) Larry Page ve Sergey Brin (Google kurucuları) Jeff Bezos (En büyük internet satış sitesi Amazon.com kurucusu) Berry Brazelton (Pediatrist ve yazar) Helen Hunt (Başarılı oyuncu, en iyi kadın oyuncu dalında 46 ödül sahibi) Sean Combs '’Puffy Daddy' (Birçok ödül sahibi rap yıldızı) Prens William ve Prens Harry (İngiliz kraliyet ailesi mensupları) Katharina Graham (Washington Post'un eski sahibi) Will Wright ("The Sims" bilgisayar oyunu yaratıcısı) Steve Wozniak (Apple'ın kurucu ortağı) Jimmy Wales (Wikipedia kurucusu)(ninniperisi.com,2017)

Eğitim politikaları içine 21 yy becerilerinin ve Montessori Eğitim yaklaşımının yerleştirilmesi bir süreç olacaktır, bu süreçde tüm eğitim paydaşları ile birlikte 21. yüzyılda Türkiye'nin sahip olmayı hedeflediği insan modelinin ortaya konması ve ülkemizin ihtiyacı olan becerilerin önceliklendirilmesi gibi teori amaçlı çalışmalar yapılmalıdır. Erken çocukluk eğitimini de mutlaka içine alacak sistem bütünlüğü hedeflenmelidir. İl, ilçe, okul yöneticileri, öğretmenler ve veliler için ortak çalışmalar düzenlenerek 21 . Yy becerilerinin kazanılmasının okul öncesinde başlaması ve bunun Montessori eğitimi ile ilişkilendirilmesi sağlanmalıdır. Milli Eğitim Bakanlığı Merkez teşkilatının erken çoculuk daire başkanlığının il, ilçe ve okulöncesi kurum yöneticilerinin koordineli birbirini destekleyici bir tutumla 21.yy becerileri ve Montessori Modeli bir eğitim öğretim sürecine liderlik etmesi gerekir. Bu eğitim modelinde öğretmen kuşkusuz en önemli paydaştır. Öğretmen adayları mesleğe başlamadan hizmet öncesi eğitimler ile bu konuda desteklenmelidir. 21.yy becerileri odaklı bir öğretmenlik formasyonu ise olabilecek en doğru çözümdür.

Hâlihazırda görev yapan öğretmenler bu uygulamalar için profesyonel desteğe ihtiyaç duyacaklardır. Bakanlığın bir sanal platform ile bunu desteklemesi uygulamaların doğru yapılması için şarttır. Yine okul öncesi ders içerikleri ve müfredat kaçınılmaz olarak değiştirilmelidir. En önemli değişimin yaşanacağ öğrenme ortamları kesinlikle Montessori Eğitim Yaklaşımının önerdiği doğrultuda düzenlenmelidir. Beceri temelli erken çocukluk eğitimi farklı bir eğitim kültürünün oluşumunu gerektirmektedir. Süreci değerlendirmek için 2023 vizyon belgesinde vurgulanan becerilerin kazanılmasında her öğrenciye ait eportfolyo tutulması mutlaka gerçekleştirilmelidir. Yine öğretmenlere, yöneticilere, öğrencilere ve velilere 21 yy becerilerinin kazanılmasında Montessori eğitim modelinin doğru örnekleri gösterilmeli ve eğitimler verilmelidir. Çocukla ilgili tutulan e-porfolyoların kademeler arası sürdürülebilirliği de sağlanmalıdır.

21.yy becerileri ile donanmış bireyleri istihdam eden iş çevreleri, kültür sanat çevreleri belediyeler, müzeler ile danışma ve iş birliği toplantıları düzenlenebilir. Bu toplantılar ile içerik planlamaları, faaliyetler ve eğitim destekleri sağlanabilir. Bu süreçlerin tamamlanıp ülkemizin eğitim politikları içinde yer almasına kadar okullar eğitim ortamında çocukların özgürce hareket etmelerini sağlayarak çocukların araştırma yapma, iletişim kurma ve cesaretlerini artırmalıdır. Erken çocukluk eğitiminin 21 yy becerilerinin ne kadar önemli olduğuna ilişkin, uygulamaları da içeren kitaplar hazırlanabilir. Bu çalışmanın sonuçlarını dikkate alarak 21 yy becerilerinin kazanılmasında zaman kaybetmemek için okul öncesi eğitim kurumlarında uygulanan programlara ek olarak Montessori eğitimi de uygulanarak programlar bu doğrultu da zenginleştirilebilir.

$\mathrm{Bu}$ çalışma 21.yüzyıl becerileri ve Montessori eğitim yöntemini 4-5 sayfaya sığdırma bağlamında bazı sınırlılıklar barındırmaktadır. Her iki kavramda literatür açısından oldukça geniştir. Araştırmacı ulaşabildiği tüm kaynaklardan yararlanmıştır.

Milli Eğitim Politika yapıcıların bu konulara duyarlı ve bilgili olmaları ile ancak bu öneriler hayata geçirilebilir. Yapılan bu çalışmanın Milli Eğitim Bakanlığına görüş olarak sunulması ve bu konuda yapılacak başka çalışmalara da kaynaklık etmesi hedeflenmektedir. 
International Journal of Scientific and Technological Research

ISSN 2422-8702 (Online), DOI: 10.7176/JSTR/6-06-15

Special Issue of Educational Sciences, Vol.6, No.6, 2020

\section{KAYNAKÇA}

CASTRELLI, V. (1944). İtalya’da Entelektüel Hayat İstatistikleri, Çev: Nüzhet Yakut.

HAMARAT, Ercenk (2019) 21.SETA /Analiz Raporu, 21.Yüzyıl Becerileri Odağında Türkiyenin Eğitim Politikaları

KRAMER, R. (1976). Maria Montessori: A Biography. New York: Putnam. Reprint, Reading, MA: Addison-Wesley, 1988.

MONTANARO, S.Q., (1991). Understanding the human being. The Importance of the First Three Years of Life (The Clio Montessori Series). Published: ABC-CLIO, 99 - 101.

MONTESSORİ, M. (1982), Çocuk Eğitimi, Montessori Metodu (2. Baskı), İstanbul, Sander Yayınları.

MUTLU,B.,ERGIŞ̦i,A.,AYHAN,B.,A.,ARAL,N.,(2016) Okul Öncesi Dönemde Montessori Eğitimi Sağlı Bilimleri Dergisi 13, 113-128

OĞUZ, V., AKYOL,K.,A.,( 2006, ) Çocuk Eğitiminde Montessori Yaklaşımı, Ç.Ü. Sosyal Bilimler Enstitüsü Dergisi ,Cilt:15 sayı 1 243-256

TÜRK SANAYİCILER VE İŞ ADAMLARI DERNEĞİ (Mayıs, 2005). Yayın No. TÜSİAD-T/2005$05 / 396$

WILLIAMS, M. (1996). Plato, Piaget, and Montessori: A Study of Development Theories. Unpublished dissertation thesis, Baylor University, Texas.

WORLD ECONOMIC FORUM RAPORU (2015) World Economic Forum, New Vision for Education: Unlocking the Potential of Technology, Cenevre.

\section{INTERNET KAYNAKLARI}

https://tegm.meb.gov.tr/dosya/okuloncesi/ooproram.pdf

www.cantayayinlari, mesut hayat, Erken Çocukluk Döneminde Özel Eğitim Hizmetleri ve Erken Çocukluk Eğitimi Yaklaşımları Semineri

https://ninniperisi.com/2017/06/02/ninni-perisi-montessori-egitimi-almis-unluler/ 